\title{
European Union- South Asia Development Co-operation with special reference to India
}

\author{
JAYARAJ AMIN \\ Mangalore University \\ jayarajamin@yahoo.com
}

\begin{abstract}
The scope of the EU's development agenda has undergone significant changes over the years and now, interalia, includes political objectives and sectoral priorities. In South Asia - a region long overlooked by the EU due to its marginal presence in global trade, internal bickering and varying political preferences - the EU is now focussed on improving infrastructure and social sectors, in addition to its longstanding liberal contributions of assistance in response to natural disasters in the region. The wider implications of donor coordination and EU development strategy are subject to much scrutiny and debate in South Asia, as this aid is inextricably linked to political preferences. This article evaluates the nature of the EU's development programme in South Asia. It also points to the contradictions that exist within the EU's larger ideological preferences and actions in its development agenda in South Asia.
\end{abstract}

Key words: Development cooperation, Economic assistance, EU external relation, EU-India, EU- South Asia, SAARC

\section{Introduction}

Over the years the European Union's (EU) development cooperation policy has undergone significant changes in its reach, pattern and scale. Today the EU and its Member States are the major donors of development aid to developing countries, contributing more than $€ 49$ billion in 2008 , which is equivalent to $0.40 \%$ of their GNP, and this target is set to reach $0.7 \%$ in $2015 .{ }^{1}$ Much of the aid is provided by Member States to others through bilateral arrangements and often the EU is expected to follow the guidelines worked out by Member States; yet, the development programmes and policies have become indispensible activities of the EU. Their importance has increased in view of the EU's (the Commission acting on behalf of the Member States) substantial influence in global economic relations. Significantly, the Maastricht Treaty on the European Union that introduced a legal status to the development policy, stresses the principles of complementarity (of Member States' policies, programmes and EC action)

$1<$ http://europa.eu/pol/dev/index en.htm $>$, accessed 14 January, 2012. 
as well as coordination (between two or more development partners and policies) and coherence (operation without contradiction in policies and programmes) to improve the effectiveness of the policy, indicating the status EU enjoys in the economic operation of European countries.

\section{The Nature of EU development cooperation policy}

The EU's development cooperation policy often overlaps with its trade policy. The objective of the policy is to develop and consolidate democracy and the rule of law and to foster 'sustainable economic and social development,' 'smooth and gradual integration into world economy' and to contribute to 'campaign against poverty" in the developing countries. ${ }^{2}$ The emphasis on the eradication of poverty was further highlighted by the EU along with the UN General Assembly adoption of Millennium Development Goals (MDG) in 2000. The EU has steadfastly supported the MDGs and incorporated them into its development policy. The development policy enables the EU to conduct regional agreements, which grant certain privileges alongside humanitarian aid, special funds for poverty and eradication campaigns. The EU's liberal values are further evident in measures employed by the EU to achieve this objective. These include capacity building, involvement of the private sector and civil society and balance of payment or budget support to governments to help meet transitional costs. 3

Notably, the emphasis on core EU values in its external economic policy framework has increased over the years, as the EU has added trade and development policies to its traditional donor coordination role. The end of Cold War, globalisation and the belief in the supremacy of democratic values have prompted the EU to increasingly make use of its external policy framework to structure bilateral relations as well as to develop the world economy in line with its core values. Indeed the EU sees an improved strategic coherence between its aid, trade and development policies. There are instances abound of the EU making use of its economic leverage, including suspension of aid to coerce the target country to accept EU view points. The 2005 policy statement entitled 'European Consensus on Development' suggested that sustainable development should include good governance, human rights and political, economic, social and environmental aspects (clause 7), and put an emphasis on reducing poverty, focussing on the MDGs and conducting 'development based on Europe's democratic values.' 4

Hence, "economic cooperation," Commission jargon for new type of development aid, aimed at improving the macroeconomic and business infrastructure of countries and regions through trade, investment and business promotion schemes is being increasingly used by the EU. It is in these 'new generation agreements' that the EU's

\footnotetext{
2 Treaty on European Union, European Communities (Luxembourg, 1992); Title XVIII, Article $130 u$. This article 130u is renumbered as article 177 (Title XX) in the Treaty of Amsterdam 3 Communication from the Commission, Regional economic integration efforts, II European Community support to integration efforts throughout the developing world, Development, collection,vol.2,06/9611/97, <http://europa.eu.int/comm/development/_recueil/en/en13/en131_2.htm>, accessed 14 January, 2012.

4 <http://ec.europa.eu/development/policies/consensus_en.cfm>, accessed 14 January, 2012; Official Journal of the European Union C 46/1 24.2.2006 EN, $<$ http://ec.europa.eu/development/icenter/repository/european_consensus_2005_en.pdf>, accessed 14 January, 2012.
} 
political objectives are often apparent; and, since the 1990s most of these agreements have come to include EU concerns from human rights to democratic principles to labour standards to good governance. In fact the EU has even introduced a novel 'GSP-Plus' incentive to support 'sustainable development and good governance' if a 'vulnerable' country has signed 16 human rights conventions and at least seven (out of the eleven) conventions on environment and governance. In other words, political priorities are closely aligned with economic policies. This is also evident in the 'Country Strategy Paper' (CSP) (2007-2013) that the EU began to develop from 2006 onwards for each country, in which the objectives and basis of cooperation are clearly spelt out.

The examination of the EU's development approach reveals certain trends. The EU's approach to development is not merely guided by economic considerations; political objectives, as observed above, are a clear motivator. Although regional and global strategies still exist and support to regional organisations continue, the EU is increasingly showing an interest in bilateral agreements. This is perhaps due to a realisation of the limitations of adopting sweeping global positions. Bilateral relations also better enable the EU to attach preferred values in such relations.

The EU is increasingly showing interest in aligning itself with national development strategies, created by concerned governments and focussing on sectoral priorities. Here the emphasis is on effecting structural reforms, rather than on support for independent projects. In fact, the 2005 'European Consensus on Development' policy statement suggests that developing countries have the primary responsibility for creating and enabling a domestic environment for mobilising their own resources, including conducting coherent and effective policies (developed in collaboration with nongovernmental bodies) and the EU will align with these national strategies. 5 In other words, there is increasing emphasis on 'structural reforms' in the target country to realise the political and economic objectives of the EU. There is now a marked emphasis on 'dialogues' as a means to structure development cooperation and this often serves to achieve the EU's political objectives. Dialogues would also imply the negotiations keeping in mind the final beneficiaries. This in turn has increased the number of actors and stakeholders in the process. Hence, the EU is increasingly involving civil society and NGOs in development activity since it believes that wider participation is not only helpful in implementation of development policy but is also a constituent part of good governance. A focus on good governance has become the main component of EU's development strategy.

There is an increasing stress on 'reciprocity' along the lines of the Most Favoured Nation (MFN) enumerated in GATT/WTO and, declining interest in the GSP scheme based on 'Special and Differential Treatment' (SDT) permitted by GATT/WTO rules under 'objective criteria' (such as level of development). This is in particularly evident in the ACP-EC-Partnership Agreement or Cotonou agreement of 2000. Even when formal agreements take place, its benefits are nullified by EU's counter measures as could be observed in EU multi-lateralised initiative of 'Everything but Arms' (EBA) which provided duty-free and quota-free access to the EU's market for exports from LDCs. ${ }^{6}$

5 Development/policies., ibid

${ }^{6}$ Gerrit Faber and Jan Orbie, "The New Trade and Development Agenda of the European Union,"

Perspectives on European Politics and Society, vol.9, No.2, June 2008, pp. 192-207; 
These measures among others include restrictions on the ground of 'sensitive' products i.e. primary products of developing countries from having easy entry into EU market besides variety of obstacles in the form of NTBs, VERs, etc and EU higher tariff rates making exports to Europe prohibitive.

Closely related to this, there is an increased move from unilateral trade preferences to capacity building, regulatory mechanisms and 'Aid for Trade' (AfT) policy (to increase trade policy capacity of developing countries including policy making, negotiation, public-private networking; enable informed choices; financial institutional reforms, improved infrastructure; adjustment assistance etc.) to better integrate with world trading systems.7 In this policy trade and development goals are linked and the presumed benefit of market mechanisms, such as inclusive growth, a dynamic financial market, macro-economic stability and institutional quality are held to be conducive to development and at the same time, to multilateralism. In this view, the market values of the EU are seen as universally applicable and ultimately beneficial to every country. Therefore, the EU finds no contradiction between its stated goals of multilateralism and an increasing number of bilateral agreements focussed on the common good, even though the latter has led to a significant decrease in the number of unilateral concession agreements. At times its preferred version of development has faced the problem of getting converted into agreement because of the political sensitivities involved. Nevertheless, the number of bilateral agreements conducted by the EU has increased along with the EU's attempt to progress the global approach to issues.

\section{EU South Asia Development cooperation}

The countries of South Asia were basically former colonies of the British Empire and the association with Britain continued even after their independence. This, however, did not prevent South Asian countries from establishing closer relations with other European countries despite the EC's initial focus on Africa. In fact, India was one of the first countries to establish diplomatic relations with the six members of the EEC in 1962. Countries of South Asia, in particular India and Bangladesh, were the major beneficiaries Food Aid Convention in 1967 approved by the EEC. ${ }^{8}$ The first programme of financial and technical assistance to non-associated developing countries in 1976 to meet cost of food aid and rural development was also beneficial to South Asia. 9

Nevertheless, it was the GSP provisions, which the by EC evolved in 1971 that became the framework for the EC's trade relationship with most developing countries outside

http://europa.eu/pol/dev/index en.htm; Christopher Stevens, "The EC and the third world," in D. Dyker (ed.), The European Economy. London, Longman. 1992. pp. 211-229.

$7<$ http://ec.europa.eu/development/policies/ginterventionareas/trade/aid-for-trade en.cfm $>$, accessed 15 January, 2012.

8 Under the food aid convention during the period 1970-74, India and Bangladesh became the top recipients of EEC's aid with $6.5 \%$ and $6.4 \%$ respectively of the total aid committed. See, F. Birocchi, "The European Union's Development Policies towards Asian and Latin American Countries," DSA European Development Policy Study Group, Discussion Paper No. 10, February 1999, <www.

Edpsg.org/Documents/DP10.doc>, accessed 15 January, 2012.

9 http://aei.pitt.edu/4174/o1/o01630_1.pdf 
the ACP including South Asia. The inclusion of Britain in the EC brought countries of South Asia, in particular India, closer to EC countries. The first agreement with India was signed in December 1973. In June 1981 this developed into an agreement for commercial and economic cooperation ; trade issues dominated without prescribing any conditions, such as the implementation of specific policies. Therefore, in the initial stages the EC, with a limited number of members and without global ambitions, extended humanitarian assistance and economic benefits came without any conditions attached, although it cannot be denied that Cold War politics did influence some of its choices, especially in East Asia.

However, in the late 1980 os changes in both the European and the global situation, such as the signing of the Single European Act and the creation of the Common Market, the end of Cold War and Soviet disintegration, changes in East Europe and its inevitable ramifications on the EC, faster economic progress in South East Asia, to name a few, influenced the EC's relation with rest of the world. The new role that EC assumed in the changed situation was also reflected in the nature of development cooperation with developing countries. With the apparent triumph of liberal democracy and market forces, the EC was now bent on reclaiming its global influence, which had been limited during the Cold War period and advancing the values dear to its heart. Therefore, a sustained position was now seen as necessary. The EC now began to work closely with the IMF and the World Bank as well as with its own Member States like France, Britain and Germany who were determined to have a rule-based regulatory global mechanism for market operation.

The EU was now determined to increase its presence as well as visibility in fast growing Asia. This was visible in its policy documents. For instance, the 1992 Council regulations (EEC) extended financial and technical assistance and economic cooperation to Asian countries but not without losing sight of its political preferences - promotion of human rights, democratisation and good governance along with trade liberalisation and strengthening cultural dimension. ${ }^{10}$ The growing strength of Asia was now recognised and the desire of the EC to strengthen its presence in the region was further evident in its "Towards a new Asia strategy," formulated in 1994, which advocated a pro-active policy in Asia and foresaw advantages in associating with Asia as well as in helping them "to integrate to the open, market based world trading system." ${ }^{11}$ South East Asia was its area of focus but at the same time it held that "there are signs that South Asia too could enjoy higher economic growth in next ten years, especially if the momentum of restructuring is maintained." ${ }^{12}$ The growing importance EU now attached to Asia was further evident in its revised strategy in 2001 which was formulated against the backdrop of South East financial crisis of 1997, WTO reforms, the EU's deeper integration, accelerating economic development in India, and nuclear tension between India and Pakistan. The strategy paper noted the South Asian problems relating to

10 Council regulation(EEC) No.443/92 of 25 February 1992 on Financial and Technical Assistance to, and Economic Cooperation with, the developing countries in Asia and Latin America.

11 "Communication from the Commission to the Council," Towards a New Asia Strategy, COM (94) 314

final, Brussels 13-07-1994. <http://europa.eu.int/comm/external relations/asem/asem process/

com95. htm>, accessed 15 January, 2012.

12 Ibid. 
Kashmir issue, terrorism, and religious fundamentalism and it called for restoration of democracy in Pakistan.

Significantly it felt the need to prepare a comprehensive economic and commercial treaty towards South Asia, increase dialogue on trade and liberalisation and policy reform among others. ${ }^{13}$ This was realised in five cooperation agreements that the EU signed with five countries of South Asia between 1994 and 2004; but, as outlined in the 'EU-SAARC (member countries) partnership and development cooperation agreements' the basis of all agreements (in South Asia) was the 'respect for human rights and democratic principles' though treaties aimed to 'enhance and develop two-way trade and promote investment, improve economic, technical and cultural links, support overall sustainable development and protect the environment.' ${ }^{14}$ So, the EU has sought to develop a multi-faceted relationship with South Asian countries but not without its clear political priorities.

Notwithstanding, the EU-South Asian relations at the bilateral level have steadily grown. But the nature of relationship has varied across the region. For instance, the EU has a closer relationship with India than other South Asian countries. India is both a donor and recipient of EU FDI with EU investment of $€ 3.0$ billion (2010) in India and Indian investment of $€ 0.6$ billion in EU. India and Pakistan happen to be major trading countries with the EU with $13.8 \%$ and $12.4 \%$ of imports and $18.7 \%$ and $22.6 \%$ of exports respectively in 2010.15 But, the overall statistical figures suggest that while in the extra-EU trade South Asia's share is less than $2 \%$, the EU's position in South Asia's external trade is over $20 \%$. In other words, the EU is extremely important to the countries of South Asia but in terms of trade the reverse is not true.. But EU-South Asian relations have moved beyond pure commercial transactions. The relationship between the EU and South Asia is multi-layered, despite South Asian countries complaining about the EU's high level of community-wide standards, coupling noneconomic issues like human rights with trade issues, subsidies to EU farmers far beyond the WTO prescription, the EU's complicated business procedures; and, on the other hand, the EU's issues with highly regulated markets, NTB's in the form of import licensing, lengthy customs procedures which pose barriers to trade in South Asia. ${ }^{16}$

\footnotetext{
13 "Communication from the Commission," Europe and Asia: A strategic framework for enhanced cooperation, COM (2001) 469 final, Brussels,04-09-2001.

14 The aim of development cooperation in South Asia was stated to be 'sustainable development and social progress.' But it also included large number of other cooperation areas apart from trade and economic cooperation and science and technology cooperation - creating favourable climate for investment(with India, Nepal and Sri Lanka); expand industrial production base (India and Pakistan); protection of intellectual rights (India and Sri Lanka); Information, culture and communication( Pakistan and Bangladesh); Energy(India, Pakistan and Nepal), prevent drug and money laundering( Pakistan and Bangladesh); and, Tourism (India, Pakistan and Sri Lanka).

<http://europa.eu/legislation summaries/external relations/ relations with third countries/ asia/r14102 en.htm $>$, accessed 15 January, 2012.

$15<$ http://ec.europa.eu/trade/creatingopportunities/bilateral-relations/countries/india $>$ and $<$ http://trade.ec.euroopa.eu/doclib/docs/2006/September/tradoc 113431.pdf >, accessed 15 January, 2012.

$16<$ http://ec.europa.eu/trade/creating-opportunities/bilateral relations/countries/>, accessed 15 January, 2012.
} 
Therefore, the numbers of bilateral agreements have gone up and revised agreements are being replacing the earlier ones. For instance, the first of these agreements was concluded with India in 1973 followed by Pakistan, Sri Lanka and Bangladesh. The EC concluded three agreements with India, one for each generation $(1973,1981,1994)$ and each of these was more comprehensive than the preceding ones. Pakistan conducted a second generation agreement in1986 and finalised its third generation agreement in 2001, which entered into force in 2004. Sri Lanka went directly from a first generation agreement in1975to a third generation Cooperation Agreement on Partnership and Development (CAPD) agreed in 1994 and effected in 1995. Nepal, a late comer went straight to a third generation cooperation agreement in1996. The second generation agreement with Bangladesh (1976) was replaced by the third generation cooperation agreement (2001) that included dialogue on development, trade and governance issues. Fully-fledged formal cooperation agreements with Bhutan and the Maldives are yet to be concluded although these countries have been receiving development assistance from the EU.

These agreements and the dealings of the EU with South Asia, however, are not solely based on economic considerations and the politics of the time had significant impact on them. For instance, although Pakistan negotiated a third generation agreement in 1998 its acceptance was postponed till 2001 for political reasons: the nuclear test of 1998, Kargil war, and the military takeover in 1999. Only after Pakistan changed its policy on Afghanistan in the aftermath of 9/11 and joined the 'war against terror' was the third generation agreement concluded. Similar delays occurred in the acceptance of the Country Strategy Paper (CSP) due to EU adverse report on electoral flaws in the general elections of October 2002 in Pakistan. ${ }^{17}$ Conversely, Pakistan was rewarded by being included in the list of GSP drug regime countries which were entitled to additional trade preference and it was clearly guided by foreign policy considerations after Pakistan changed its Afghan position in the aftermath of 9/11. Similarly, Sri Lanka became the only Asian country and one of only 15 countries to benefit from a social incentive system when the European Commission granted it GSP Plus status in 2005 (under which unilateral beneficiaries of other EU's Asia-wide programmes such as Asia Invest, Asia Urbs, Asia Pro Eco, Asia IT \& C and Asia Link.18

Nevertheless, the objective of the EU in South Asia, as in other regions, is to make development more inclusive and to deepen the structural reforms including better governance and infrastructure. But the Western notion of governance would not be complete without a civil society component. Hence, along with support for government activities, support to civil society activities and evolving 'political dialogues' are constituent parts of the EU's approach in South Asia. These are perceptible in CSPs and, particularly evident in the action plan (as in the case of India). Moreover, in South Asia, it is difficult to separate the EU's development aid from economic cooperation as the objectives often overlap.trade concessions are granted to developing countries that ratify

\footnotetext{
17 Jean-Luc Racine, 'European Union and South Asia : An appraisal,' August 2003, <http:// celas.ehess,fr/ docannexe.php?id=1055>, accessed 15 January, 2012.

18 European Commission, Strategy paper and indicative programme for multi-country programmes in Asia 2005-2006.
} 
and implement 27 international conventions on core human rights, labour rights and conventions on environment and good governance principles). ${ }^{19}$

In other words, the development cooperation policies of the EU in South Asia served two purposes. First, it helped to maintain linkages and to ensure a presence in an area that is prominently emerging on the world scene for a number of reasons. Second, the EU's development policies in South Asia advanced its core values. However, in practice, each agreement had to be country specific because of the sensitivities and specific conditions in South Asia and also because of the bilateral problems in the region that prevent the implementation of regional strategy. It is here that the bilateral agreements that the developed with each country were important, as they indicated both the level of EU relations with that country, and the priorities and areas of cooperation. In addition to this South Asian countries like other Asian countries were

\section{EU and South Asian Development Cooperation}

All South Asian countries have enjoyed close cooperation with the EU and all the major beneficiaries of EU assistance. But the nature of the relationship is varied. The EU's relationship with India is deep and has concluded a variety of agreements with many EU countries. A regular political dialogue was started at the first Summit of 2000. Since the 2004 Summit this dialogue has taken the form of a Strategic Partnership, making India one of the EU's select six global partners. The 2005 Joint Action Plan (JAP), revised in 2008 to implement the multi-dimensional EU-India Strategic Partnership that commits both parties to strengthen dialogue, deepen pluralism, democracy, regional cooperation, fight against terrorism, and encourage people to people contact It also calls for cooperation in S \&T, ICT, Transport, Environment and Climate Change, Civil Aviation, Security dialogue, Economic Development, Energy, Trade and Investment etc. India the EU have also found new platforms of dialogue through Indian membership of the Asia-Europe Meeting (ASEM) and the EU's observer status at SAARC summits. This multi-faceted agreement is in contrast to the relations of Bhutan and the Maldives who are yet to conclude comprehensive bilateral agreements with the EU.

The EU has responded positively whenever South Asian countries are affected by natural disasters. For instance, Sri Lanka was provided with humanitarian assistance of $€ 95$ million in 2005-06 under the Tsunami Indicative Programme of the Commission (May 2005) to overcome the effects of 2004 Tsunami. This was also the case with the Maldives who received $€ 20$ million as post-tsunami humanitarian and reconstruction assistance. The Commission provided assistance of $€$ 98million for relief and reconstruction in Pakistan after the October 2005 earthquake in addition to substantial assistance through other avenues for the Afghan refugees in Pakistan.

Countries recovering from man-made disasters were also given a helping hand by the EU. For instance, much of the assistance to Nepal was structured around post-conflict recovery and stability aspects. This is evident in the Country Strategy Paper (CSP) for

19 http://www. Dellka.ec.europa.eu/en/eu and srilanka/trade/gsp.htm, accessed 15 January, 2012. 
Nepal that earmarked $€ 120$ million (2007-13) in EU assistance for Education (with human rights, conflict prevention and good governance as cross-cutting issues), Stability and Peace building beside trade facilitation and economic capacity building. ${ }^{20}$ These in addition to other packages extended by the EU to Nepal in the form of grants to Conflict Mitigation Package I and II, Economic Cooperation and Capacity building project (support to SME) etc. The EU was prepared to join hands with the Nepalese government's three year interim plan (2008-10) that focussed on infrastructure, economic and social sectors.

Apart from humanitarian assistance, the EU is actively supporting advancements in the social sector. So the EU has prioritised human and social development (35\%) in its budget allocation to Bangladesh; its Vulnerable Community Package in Nepal; assistance of $€ 190$ million to three major government projects in Pakistan, consisting of Social Action Programme (aimed at improving the quality and cost effectiveness of basic service delivery in four sectors: elementary education, basic health, reproductive health, and rural supply and sanitation); Rural Social Development Programme (aimed at enhancing the capacity of local NGOs to complement government efforts in social sectors) and Environmental Rehabilitation Project in NWFP and Punjab (aimed at increasing capacity of local communities to plan and manage their natural resources in a sustainable and economic manner). ${ }^{21}$

Governance, capacity building and human rights are the other priority areas for the EU. Hence, noting the 'low absorption capacity' of Bangladesh government institutions (resulting in low level of earlier disbursements) the EU reserved about $25 \%$ of its budget for governance and human rights related aspects; support for the Office of the High Commission on Human Rights (OHCHR) and Economic Cooperation and Capacity Building Project (support for SME). In Nepal, trade and good governance are mentioned (including electoral reforms, human rights monitoring and conflict resolution). EU support in Sri Lanka focuses on government and capacity building, as it does in Bhutan and the Maldives. ${ }^{22}$

Environment and conservation of natural resources (Pakistan, Bhutan, the Maldives), Rural development (Nepal, Sri Lanka, Maldives, Pakistan), Education (Nepal, Pakistan) and support to NGOs (Pakistan) are other areas of cooperation with South Asian countries beside trade and economic development. The following table provides an overview of the EU development commitment (sector-wise) from 2007 to 2013 mostly through the Development Cooperation Instrument (DCI) to the countries of South Asia (including Afghanistan) that are also the beneficiaries of other EU thematic programmes and financial instruments.

$20<$ http://ec.europa.eu/external_relations/nepal/docs/o7_13_en.pdf $>$, accessed 14 January, 2012.

${ }^{21}<$ http://www.delpak.ec.europa.eu/eupakcoop/ecPakDevCoop.htm\#Social >, accessed 14 January, 2012.

22 See, Country Strategy papers, <http://ec.europa.eu/external relations/>, accessed 14 January, 2012. 
Development Cooperation Assistance to South Asian Countries (2007-2013)* (in Million Euros)

\begin{tabular}{|c|c|c|c|c|}
\hline & Sectors & $\begin{array}{l}2007- \\
2010\end{array}$ & $\begin{array}{l}2011- \\
2013\end{array}$ & Total \\
\hline Afghanistan & $\begin{array}{l}\text { Focal Areas } \\
\text { Rural development } \\
\text { Governance \& Rule of Law } \\
\text { Health } \\
\text { Non-focal Area } \\
\text { Regional Cooperation } \\
\text { (includes Social Protection and Mine action } \\
\text { in MIP 2007-10) }\end{array}$ & $\begin{array}{r}180 \\
240 \\
20 \\
60 \\
---- \\
600\end{array}$ & $\begin{array}{l}213 \cdot 5-244 \\
213 \cdot 5-244 \\
109.8-128.1 \\
12.2-24 \cdot 4 \\
-------- \\
610\end{array}$ & $\begin{array}{l}393 \cdot 5-424 \\
453 \cdot 5-484 \\
229.8- \\
248.1 \\
72.2-84.4 \\
-------- \\
1210\end{array}$ \\
\hline Bangladesh & $\begin{array}{l}\text { Focal Areas } \\
\text { Human and Social Development } \\
\text { Governance and Human Rights } \\
\text { Economic and Trade Development } \\
\text { Non-focal Areas } \\
\text { Environment, Disaster Management } \\
\text { and Climate Change } \\
\text { Food Security and nutrition }\end{array}$ & $\begin{array}{l}58.6 \\
59.4 \\
40 \\
\\
23 \\
24 \\
---- \\
205 \\
\end{array}$ & $\begin{array}{l}74 \\
54 \\
30 \\
\\
20 \\
20 \\
---- \\
198 \\
\end{array}$ & $\begin{array}{c}132.6 \\
113.4 \\
70 \\
\\
43 \\
44 \\
----- \\
403 \\
\end{array}$ \\
\hline Bhutan & $\begin{array}{l}\text { Priority I } \\
\text { Renewable Natural Resources } \\
\text { Priority II } \\
\text { Governance and Institution Building } \\
\text { Priority III } \\
\text { Trade Facilitation }\end{array}$ & $\begin{array}{l}5.6 \\
2.8 \\
-- \\
------ \\
8.4\end{array}$ & $\begin{array}{l}2.8 \\
--- \\
2.8 \\
----- \\
5.6\end{array}$ & $\begin{array}{l}8.4 \\
2.8 \\
2.8 \\
----- \\
14\end{array}$ \\
\hline India & $\begin{array}{l}\text { Priority I } \\
\text { Social Sector (Health and Education) } \\
\text { Priority II } \\
\text { Implementation of Joint Action Plan (Pro- } \\
\text { poor sector reform, economic sector } \\
\text { dialogues and cultural, civil society and } \\
\text { academic exchanges) }\end{array}$ & $\begin{array}{l}180 \\
80 \\
-----\end{array}$ & $\begin{array}{l}150-180 \\
30-60 \\
------- \\
210\end{array}$ & $\begin{array}{l}330-360 \\
110-140 \\
------ \\
470\end{array}$ \\
\hline Maldives & $\begin{array}{l}\text { Safe Island/Climate Change, Drugs, } \\
\text { Trade and Governance }\end{array}$ & 4 & 6 & 10 \\
\hline Nepal & $\begin{array}{l}\frac{\text { Priority I }}{\text { Education; School sector reform }} \\
\text { Priority II } \\
\text { Stability and Peace Building } \\
\text { Priority III } \\
\text { Trade and Economic Capacity Building }\end{array}$ & $\begin{array}{l}36 \\
22 \\
2 \\
------\end{array}$ & $\begin{array}{l}30-36 \\
15-21 \\
3-9 \\
-60\end{array}$ & $\begin{array}{l}66-72 \\
37-43 \\
5-14 \\
----- \\
120\end{array}$ \\
\hline
\end{tabular}




\begin{tabular}{|c|c|c|c|c|}
\hline Pakistan & $\begin{array}{l}\text { Focal Areas } \\
\text { Rural Development and Natural Resource } \\
\text { Management in North-West Frontier and } \\
\text { Baluchistan } \\
\text { Education and Human Resource } \\
\text { Development } \\
\text { Non-focal area } \\
\text { Trade Development and Economic } \\
\text { Cooperation, } \\
\text { Democratisation and Human Rights and } \\
\text { Anti-money laundering }\end{array}$ & $\begin{array}{l}108 \\
64 \\
28 \\
---- \\
200\end{array}$ & $\begin{array}{l}90 \\
69.75 \\
65.25 \\
---- \\
225\end{array}$ & $\begin{array}{l}133 \cdot 75 \\
93 \cdot 25 \\
------ \\
425\end{array}$ \\
\hline Sri Lanka** & $\begin{array}{l}\text { Focal Area } \\
\text { Reconstruction and Stabilisation of the } \\
\text { North\& East } \\
\text { Non-focal Areas } \\
\text { Good Governance and Conflict Resolution } \\
\text { Development through trade programmes }\end{array}$ & $\begin{array}{l}-- \\
-- \\
--- \\
62\end{array}$ & $\begin{array}{l}54 \\
4 \\
2 \\
---- \\
60\end{array}$ & $\begin{array}{l}-- \\
-- \\
--- \\
112\end{array}$ \\
\hline
\end{tabular}

*. Compiled by the author from different Country Strategy Papers, Multiannual Indicative Programmes (MIP), MTR Document Regional Strategy for Asia 2007-2013 and Mid-term Review Documents. Source: http://www.eeas.europa.eu/; http://europa.eu/rapid/: http://finmin.nic.in/reports/AnnualReport201011.pdf; http://ec.europa.eu/europaid/where/asia/; http://www.consilium.europa.eu/

**. EU assistance during 2007-2010 was directed towards peace building process and poverty reduction; the CSP provides for flexible responses.

A noteworthy factor in EU-South Asian relations is that, all countries of South Asia were beneficiaries of EU GSP scheme. Two South Asian countries, (Pakistan under the Drug regime scheme and Sri Lanka under the social incentive scheme) are the beneficiaries of the EU's GSP plus scheme. Bangladesh is the beneficiary of Trade for Aid (TfA) provisions of EU and Nepal and Bhutan along with Bangladesh were entitled for EBA benefits. Even the SAARC despite its slow progress has been enabled by the EU to help South Asian countries. So the overall focus of the EU in South Asia is on socio-economic development in a sustainable manner, but the political priorities of the EU are manifest in most of the EU's cooperation agreements with South Asia. Political developments have influenced some of the EU's support structures. Examples of this include the Rural development and natural resource management in Pakistan NWFP and Baluchistan (given its geopolitical importance) under the Multiannual Indicative Programme (200710) and support to Pakistan in the aftermath of $9 / 11$

Another significant factor in the EU's activities in South Asia is the increasing focus on politically relevant issues like human rights, governance, capacity building and related issues, which extend beyond traditional aspects like poverty alleviation programmes, rural development and health. Equally important is the EU's stress on structural reforms and its increasing alignment with government (sectoral) policies rather than assisting specific projects. The implications of assistance are well established and assistance has evolved from a project-based project approach to a sectoral approach (in collaboration with government).

This new approach is particularly apparent in the EU's dealings with India. India is a major trade partner and India itself is becoming an active player in the global 
development scene and is both a donor (under "Indian Development and Economic Assistance Scheme - IDEAS) and a recipient of development assistance. Closer cooperation between India and the EU has led to negotiations since 2007 on the creation of the free trade pact envisaged in the Global Europe Strategy (2006). EU's several agreements with India on diverse development related issues, ranging from gender, health, environment to human rights and governance to areas of mutual interest such as education, scientific programmes and culture is in itself a recognition of the growing importance of India.

However, the EU intends to move from discrete projects to a sector budget support programme approach. This seeks to provide a certain coherence and direction in EU support to its other developmental partners. Hence, the CSP for India (2007-13) with a budget of about $€ 210$ million wishes to move the present pattern of development assistance to pro-poor 'sector reform' policies. In other words, the focus is on 'structural reforms' for increased economic growth that in turn would reduce poverty as well as facilitate better economic cooperation. So the EU's support on priority basis to the social sector (health and education) and support to economic, academic, civil society and cultural activities as foreseen in the Action plan 23 appears to be guided by the EU's new logic of development. This is best seen in the examples of EU action in the Indian social sector where the EU has joined hands with Indian programmes - Sarva Shiksha Abhiyan (SSA) and National Rural Health Mission (NRHM) - and seeks to effect changes across the sector, rather than within specific projects.

Therefore, the whole direction of EU development cooperation centres on twin principles of pro-poor sector reform and development. This is supplemented by dialogues and exchanges in diverse areas - Economic, Civil Society, Culture, Education etc. In addition, the Commission also intends to pursue 'thematic interventions' in the areas of democracy and human rights, migration and asylum, human and social development (including capacity building.) ${ }^{24}$ Support is extended in critical sectors and sectoral cooperation occurs with individual states in India. For instance, with the state of Chhattisgarh (with budget of about $€$ 16o million for 2006-12) the EU has entered into a partnership programme for improving the efficiency of critical social services (health and education) and poverty reduction of tribal communities through environmentally friendly economic strategies, and with the state of Rajastan the programme is directed towards water sector reform. ${ }^{25}$

\section{Concluding remarks}

The EU's development approach in South Asia (with the exception of humanitarian assistance during natural disasters) is becoming much more specific and refined and contains clear economic and political objectives. The development of South Development with structural reforms is actively encouraged as this approach are perceived to enhance economic prosperity. The stronger countries in South Asia, such as

\footnotetext{
$23<$ http://ec.europa.eu/external relations/india/csp/o7 13 en.pdf $>$, accessed 14 January, 2012. 24 Ibid.

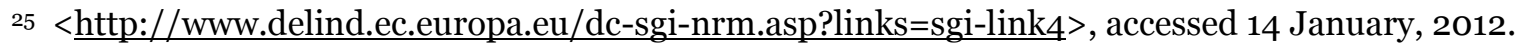


India have a greater capacity to achieve this, and different levels of cooperation are being worked out with the various countries of South Asia. Nevertheless, the overall focus of the EU in South Asia, is to build up the capacities of recipient countries and to facilitate their 'smooth integration into the global economy' with due consideration to certain values perceived to be universal by the EU.

However, the logic of EU's approach to development is not universally accepted in most South Asian countries. In these countries the word 'development' itself has vastly differing connotations and implications. The main bone of contention is that unbridled integration with the world economy is no guarantee for poverty alleviation, as the EU on one hand supports anti-poverty measures and on the other hand restricts products from developing countries from reaching its market. These policies mean that developing countries have to overcome many barriers especially NTBs in their bid to export to global or European markets, while western countries continue to protect their producers in areas critical to South Asia, such as agriculture and textiles under the guise of 'sensitive products' or other labels. This approach is supplemented by labour, human rights and other social clauses stipulating conditions that make production in South Asia extremely untenable. Therefore, the EU's support for 'capacity building' is nullified by its counter measures.

Further, there is also the complaint that EU acts conveniently in many areas that best suits its interests. For instance, tariff reductions (as the EU assured under EBA scheme) are concentrated on less tradable commodities excluding for instance, 'sensitive' products such as sugar, rice and initially bananas. Under the EBA scheme the tariff bindings in many cases were fixed at level higher than the actual tariff equivalent of NTBs (i.e. WTO 'tariffication') that applied in the base year of 1986-88. The European Union (EU), for example, had set the bindings at about $60 \%$ above the tariff equivalent of its Common Agriculture Policy (CAP) in the late 1980s, defeating the very purpose of 'tariffication'. ${ }^{26}$ Coupled with these measures are the high sanitary and hyto-Sanitary standards (SPS), which apply to marine and other food products where conditions not only relate to the quality of the product but also the process. This is also the case for other areas, for example milk products or even textiles (which affects the stronger areas of South Asia) where entry into EU market is made difficult.

In South Asia most of these products are produced in unorganised sector or by small producers. Especially in the absence of high investment, resources and technology, a lack of procedural awareness, the higher costs of compliance and specified production methods, which are not applicable to their contexts, these rigid prescriptions deter exports, as well as having a negative impact on the EU's development agenda. So the sectoral support and export-oriented structures that the EU seeks to create through development cooperation is not always compatible with its developmental goals. The 'sensitive' item clause in EU trade vocabulary and the continuing agricultural subsidies in Europe gloss over the real spirit of the EU's development agenda.

In addition, the granting of economic assistance by the EU based on political considerations has also caused dismay among other countries of South Asia. For

${ }^{26}$ See J. Amin, 'WTO and developing countries: Issues and concerns,' Jadavpur Journal of International Relations, Vol.9, 2004-2005, pp. 105-32. 
instance, the EU's extension of the GSP Plus drug regime to Pakistan in 2002, which significantly benefitted the Pakistani textile sector, upset India. India then legally challenged the EU's decision at the WTO. When the verdict favoured India, the EU had to give up its drug support regime and had to instead incorporate it within a broader governance framework. Similarly the EU's support for Pakistan in view of its changed Afghan position and its joining the 'war on terror' failed to impress India. India perceived itself to be the victim of neighbourhood terrorism. The linking of trade issues with political issues is seen as an unhealthy trend by many countries in South Asia.

However, these hiccups in EU-South Asia relations do not undermine the value of the development assistance that the EU provides to South Asia. The EU is the principal provider of the much required assistance to South Asia, even though other countries are capable of providing assistance. The shift from development aid to more commercial, non-aid EU activities in South Asia as well as a reasonably good development rate in South Asia is likely to improve the overall economic situation in South Asia. Equally important is the sensitivity that EU has shown to the unique situation in South Asia. Therefore, it would be advantageous to the countries of South Asia to become organised, transparent and accommodating in their dealings with the EU and to realise their goals of development. At the same time the EU needs to become more flexible in its approach. The dialogues already initiated between the two sides can go a long way towards finding mutually beneficial perspectives and policies. 